DOI: $\underline{10.37555 / 2707-3114.16 .2020 .219808}$

UDC: 58.02: 581.543: 633.875.33
(C) 2020 Chauhan \& Chauhan. This article is distributed under the terms of CC AttributionShare Alike 4.0 International described at https://creativecommons.org/licenses/by$\mathrm{sa} / 4.0$

\title{
Climate changes and trends in phenology of Cassia fistula L. in Agra (India)—1965-2019
}

Shyam Vir Singh Chauhan ${ }^{\bowtie}$ and Seema Chauhan

Academy of Life sciences, Kaushalpur, Agra-282005, India

e-mail: svsc071241@gmail.com

ORCID ID 0000-0002-3915-4563; ORCID ID 00000-0002-7860-5339

$\square_{\text {svsc071241@gmail.com }}$

\section{Abstract.}

Aim. The phenological observations help in identifying how plant species respond to regional climatic changes in particular such as ambient temperature. The study of trends in phenology of Cassia fistula L. (Caesalpiniaceae, Fabaceae) to climate changes in Agra (India) was the aim of the researches. Methods. The data on the average annual temperature in India and Agra were collected for 1965 to 2019 from the Meteorological Department. Commencement of leaf fall, time of new flush of leaves, flowering period (initiation, full bloom, and end) and the rest of phenophases in trees planted at Raja Balwant Singh College (Agra, Uttar Pradesh, India) were recorded from 25 marked trees during 1965-2019. Results. In C. fistula trees leaf fall started in the second and third week of February. Trees became completely leaf-less at the beginning of March. Flowering commenced in the first week of March, and the trees were in full bloom during the second week of March. Flowering continued till the beginning of May, and it was over in the second week of June. Fruiting commenced in December and continued till April. The timing of phenological events was consistent in 1965-2000. However, after 2001, there was a gradual shift recorded, and the shift was evident in 2009-2019. During the period 1965-2008, the average annual temperature ranged between $23.23^{\circ}-25.13^{\circ} \mathrm{C}$ there was a liner increase in the temperature. The increase in average yearly temperature became more pronounced in 2009, and this trend is rising in temperature continued till 2019. In Agra in 2009-2019, temperature increase by $0.75-1.0^{\circ} \mathrm{C}$ had been recorded. The shift of phenoevents in C. fistula is correlated with the rise in annual average temperature. Conclusions. The shift in 
the timing of various phenoevents is the trees of $C$. fistula at Agra (India) are influenced by the change in the climate and rise in temperature. It is suggested that a phenological model should be developed to estimate the impact of climate change on fruit trees, horticultural plants and crops development in different regions of India.

Key words: average annual temperature, flush of leaves, golden shower, Legumes (Fabaceae), phenological phases, the timing of phenological events.

\section{Тенденції фенологічної відповіді рослин Cassia fistula L. зумовлені змінами клімату в Агрі (Індія) у 1965-2019 pp.}

Шям Вір Сінгх Чаухань ${ }^{\bowtie}$, Сіема Чаухань

Академія наук про життя, Каушалпур, Агра-282005, Індія

e-mail: svsc071241@ gmail.com

ORCID ID 0000-0002-3915-4563; ORCID ID 00000-0002-7860-5339

$凶_{\text {svsc071241@gmail.com }}$

\section{Реферат.}

Mema. Фенологічні спостереження допомагають визначити, як різні види рослин реагують на регіональні кліматичні зміни, зокрема на температуру навколишнього середовища. Вивчення тенденцій фенологічної відповіді рослин Cassia fistula L. (Caesalpiniaceae, Fabaceae) на кліматичні зміни в Агрі (Індія) було визначено метою наших досліджень. Матеріали $\boldsymbol{i}$ $\boldsymbol{м e m o d u . ~ Д а н і ~ п р о ~ с е р е д н ь о р і ч н у ~ т е м п е р а т у р у ~ в ~ І н д і і ̈ ~ т а ~ А г р і ~ з а ~ п е р і о д ~ з ~} 1965$ по 2019 рр. були отримані з Департаменту метеорології. Початок опадання листя, час нового відростання листя, період цвітіння (початок, повне цвітіння та кінець) та решта фенофаз були упродовж 1965-2019 рр. вивчені на 25 розмічених деревах у Раджа Балвант Сінгх Коледжі (Агра, штат УттарПрадеш, Індія). Результати та обговорення. У дерев C. fistula опадання листя розпочиналося 3 другого-третього тижня лютого, a їх повне обезлистення наставало на початку березня. Цвітіння розпочиналось у першому тижні, а повне цвітіння — на другому тижні березня. Цвітіння тривало до початку травня, а закінчувалося на другому тижні червня. Плодоношення розпочиналось у грудні і тривало до квітня. Такий плин фенологічних подій був незмінним протягом 1965-2000 pр. Однак після 2001 року було зафіксовано поступовий зсув, з чітким зрушенням у 2009-2019 
роках. Протягом періоду 1965-2008 рр. спостерігали незначні коливання середньорічної температури у межах $23,23-25,13^{\circ} \mathrm{C}$. Більш виражене зростання середньорічної температури розпочалось у 2009, і продовжилось до 2019 року. В Агрі у 2009-2019 роках було зафіксовано підвищення температури на $0,75-1,0^{\circ} \mathrm{C}$, а зміщення фенологічних подій у C. fistula корелювало із підвищенням середньорічної температури. Висновки. На динаміку строків прояву різних фенофаз C. fistula в Агрі (Індія) явно впливають зміни клімату та підвищення температури. Пропонується розробити фенологічну модель, щоб оцінити вплив змін клімату на розвиток плодових дерев, садових рослин та сільськогосподарських культур у різних регіонах Індії.

Ключові слова: середньорічна температура, відростання листя, золотий дощ, Бобові (Fabaceae), фенологічні фази, час фенологічних подій.

Introduction. Phenological aspects of plants involve the recording of observations on the timing of their life-cycle events on leaf bud burst, flowering, and fruiting and these studies have emerged as an essential part of ecological research (Schwartz, 1999; Parmesan \& Yohe, 2003; Root et al., 2003). The phenological observations help in identifying how plant species respond to regional climate conditions and climatic changes (Chmielewski \& Rötzer, 2001). The timing of life-cycle events is excellent bio-indicator to several climate variables, such as ambient temperature (Ahas et al., 2000; Both et al., 2004).

Cassia fistula L. a medium-sized tree is commonly known as golden shower. It is a member of the subfamily Caesalpiniaceae of family Fabaceae. It is native to the Indian subcontinent and adjacent regions of Southeast Asia and widely grown as an ornamental and medicinal plant in tropical and subtropical areas. C. fistula apart from being an ornamental tree has several medicinal uses (Kumar et al., 2017; Pole, 2012; Vaidya, 2002). Duraipandiyan et al. (2012) have evaluated anticancer activity of Rhein isolated from ethyl acetate extract of $C$. fistula flowers. The results indicated that Rhein could be utilized in the treatment of cancer.

Materials and Methodology. Phenolophase in 25 marked trees of C. fistula (similar genetic conditions) growing at Balwant Rajput College, Agra, now known as Raja Balwant Singh College (R. B. S.) were recorded during 1965-2019. Agra city stretches across $26^{\circ} 44^{\prime} \mathrm{N}$ to $77^{\circ} 26^{\prime} \mathrm{E}$ and in $171 \mathrm{~m}$ higher the sea level.

Climate: The data on the average annual temperature in India and Agra were collected from 1965 to 2019 in the Meteorological Department in Agra (Anonymous, 2013, 2019). 
Plant Morphology: Morphology (height, colour and size of leaves and inflorescence) of 25 marked trees was recorded.

Phenophases: Commencement of leaf fall, time of new flush of leaves, flowering period (initiation, full bloom, and decline of blooming) in trees planted at R.B.S. College were recorded from 25 marked trees during 1965-2019.

Results and Discussion. The average annual temperature during 1965-2019 in India ranged between $23.23-25.13^{\circ} \mathrm{C}$ (Fig. 1). The annual average temperature was rising, showing a linear trend during this period.

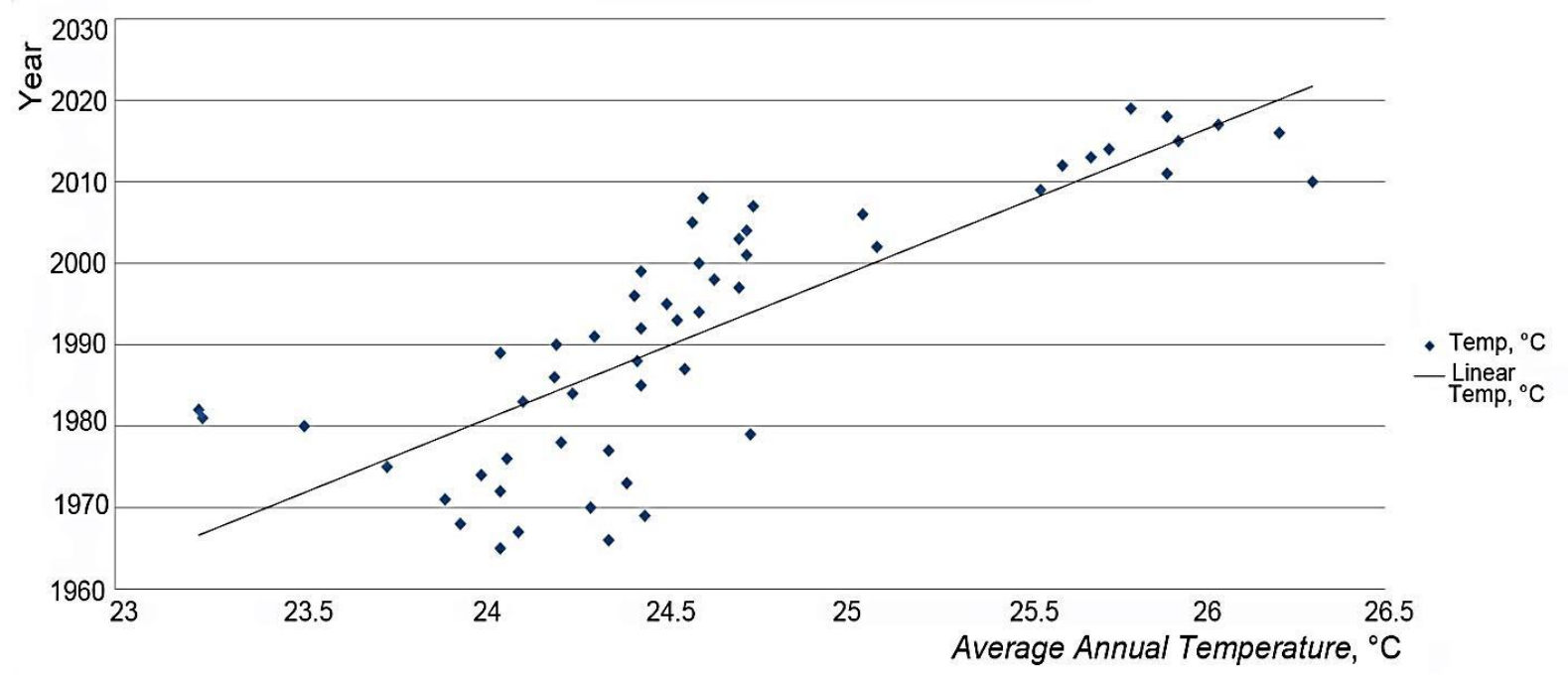

Figure 1. Average annual temperature $\left({ }^{\circ} \mathrm{C}\right)$ in North India in 2009-2019

However, after 2008, the rise in the average annual temperature was remarkably evident and was above the 1961-1990 base periods (Fig. 2).

In 2009-2010, the average annual temperature increased by $+0.91^{\circ} \mathrm{C}$ and $+0.93^{\circ} \mathrm{C}$, respectively. The rise in average annual temperature in the subsequent years showed a slightly decreased. In 2011-2012, the average annual temperature increased by $+0.8^{\circ} \mathrm{C}$ and was $+0.49^{\circ} \mathrm{C}$, respectively. In 2013, the annual temperature was $+0.35^{\circ} \mathrm{C}$, and in 2014 it was significantly warm as the annual mean temperature increased $+0.53^{\circ} \mathrm{C}$ above the average. During 2015 , the temperature was $+0.67^{\circ} \mathrm{C}$, and in 2016 the temperature was $+0.95^{\circ} \mathrm{C}$ above average.

During 2017, the average temperature was $+0.71^{\circ} \mathrm{C}$, and in 2018 it was $+0.41^{\circ} \mathrm{C}$. It was one of the warmest years in India's recorded history. The year 2019 showed a slight respite from the rise of temperature, and there was a $+0.30^{\circ} \mathrm{C}$ increase in the average annual temperature (Fig. 2). During 2019, the average temperature recorded in India was $25.8^{\circ} \mathrm{C}$, a slight decrease from the previous year from $25.9^{\circ} \mathrm{C}$. Data presented here clearly shows a rise in average temperature more than $1.0^{\circ} \mathrm{C}$ above the 1880-1900 average, and as per IMD data released by the Statistics Ministry. In India the average temperatures have increased by $0.6^{\circ} \mathrm{C}$ during 2009 2018 (Anonymous 2013, 2019). 


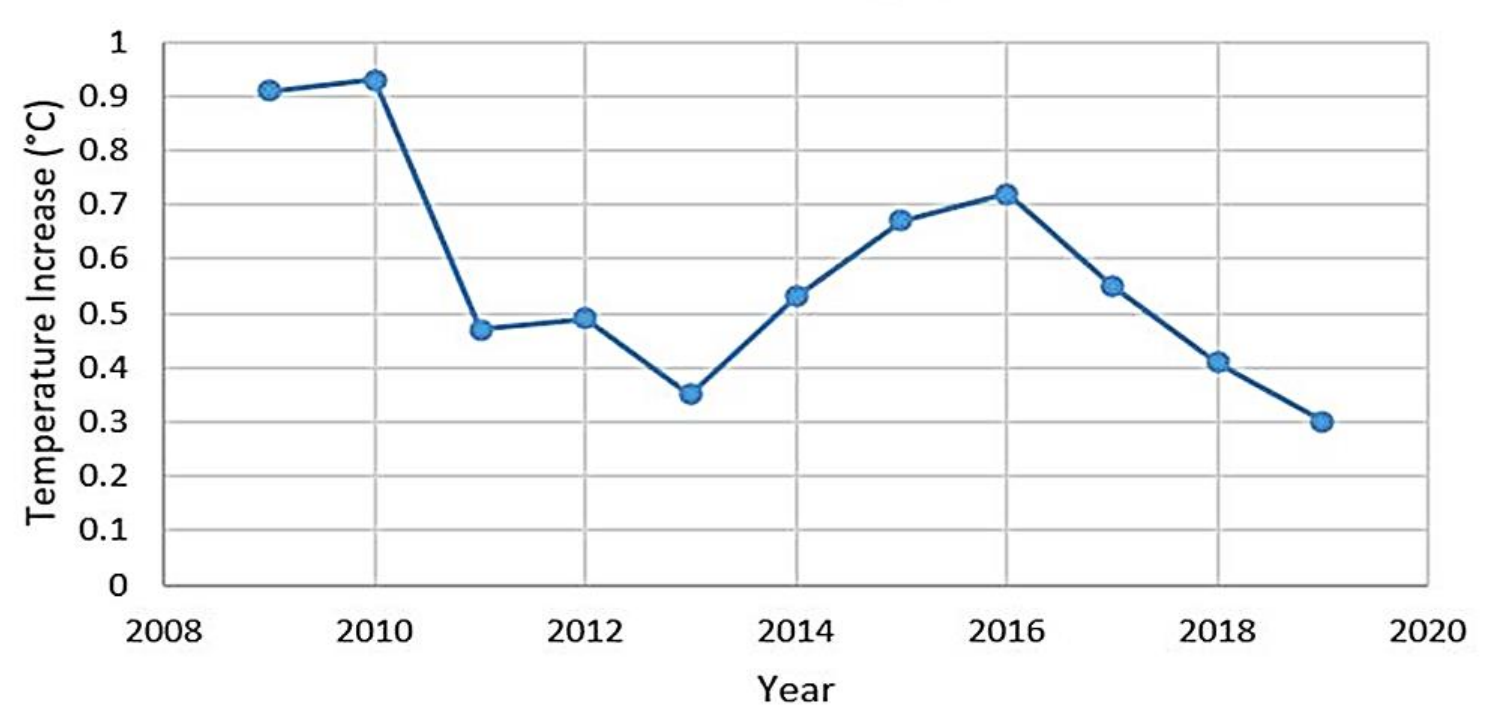

Figure 2. Increase in annual average temperature $\left({ }^{\circ} \mathrm{C}\right)$ above the 1961-1990 base periods in 2009-2019

The climate of Agra features a semi-arid climate that borders on a humid subtropical climate. Agra has a reputation of being one of the hottest and the coldest towns in India. The average temperature changes in Agra over the years and in 19652019 there was an increase of $0.75-1.0^{\circ} \mathrm{C}$. Agra is facing rising mean temperature and which is increasing at $0.18^{\circ} \mathrm{C} /$ decade annually (Misra, 2020).

C. fistula plant is a fast-growing $15 \pm 5 \mathrm{~m}$ tall tree. The leaves are dark green; $37 \pm 25 \mathrm{~cm}$ long and pinnate with $5 \pm 3$ pairs of leaflets, each leaflet is $14 \pm 7 \mathrm{~cm}$ long and $6.5 \pm 2.5 \mathrm{~cm}$ broad. The flowers are arranged in pendulous $30 \pm 10 \mathrm{~cm}$ long racemes. Each flower is $5.5 \pm 1.5 \mathrm{~cm}$ in diameter with five yellow petals of equal size and shape. Young fruits are green, but they turn dark brown on maturity and remain attached to tree till the trees bloom next year. The fruit is a legume, $45 \pm 15 \mathrm{~cm}$ long and $2 \pm 0.5 \mathrm{~cm}$ broad with a pungent odour and contained a large number of brown seeds in several compartments made by septa (Fig. 3). Several species of bees and butterflies pollinate the tree. The carpenter bees (Xylocopa sp.) were the most frequent pollinator (Murali 1993). Seeds dispersed with the help of squirrels, which feed upon the fruits and dispersed seeds by breaking the hard fruit wall.

The leaves were deciduous, and leaf fall started in the second and third week of February. The trees became completely leaf-less at the beginning of March. A new flush of leaves started with the flowering coming to an end in May. The immergence of floral buds started in the first week of March, and the trees were in full bloom in the second week of March and remained till the beginning of May. By the end of May, the flowering declined, and in the last week of June, flowering was over. The timing of different phenological events was consistent during 1965-2000. However, a shift in the timing of phenophase started gradually after 2001. The shift in the timing 
of various phenoevents was evident in 2009, which continued in 2019. The leaf fall started in the first week of March, and the trees were leafless at the end of March. Flowering was delayed and commenced in the first week of April and continued till the end of July. In a limited number of trees, flowering was recorded in the second week of August also. Fruiting commenced in December and continued till April.

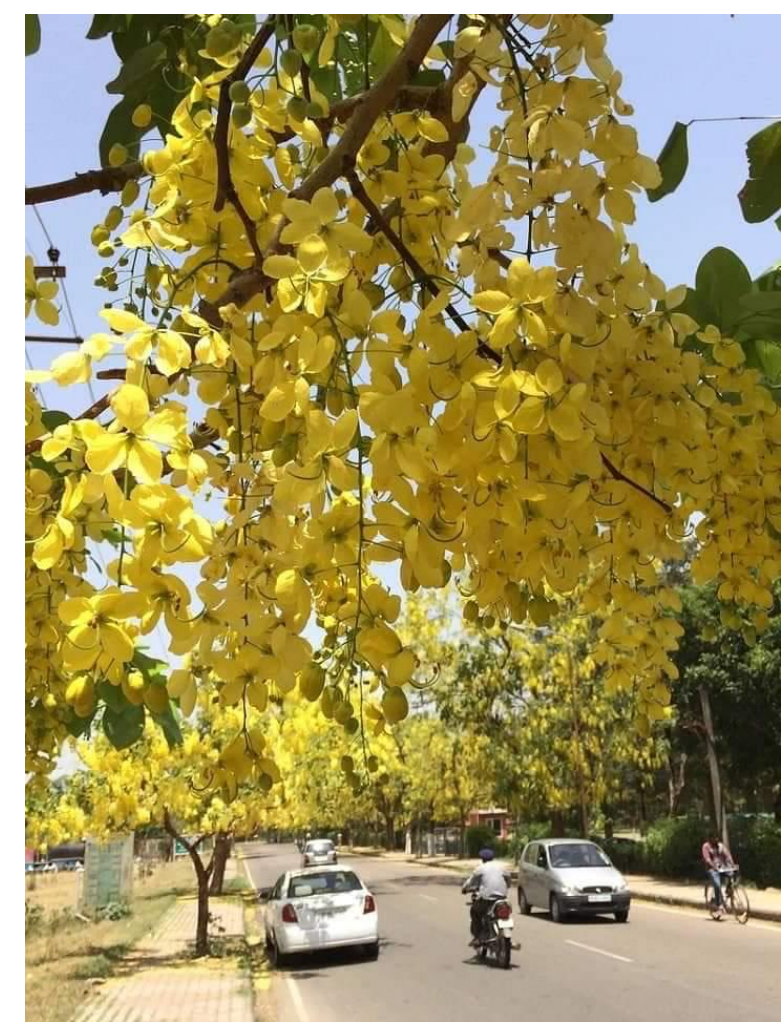

$a$

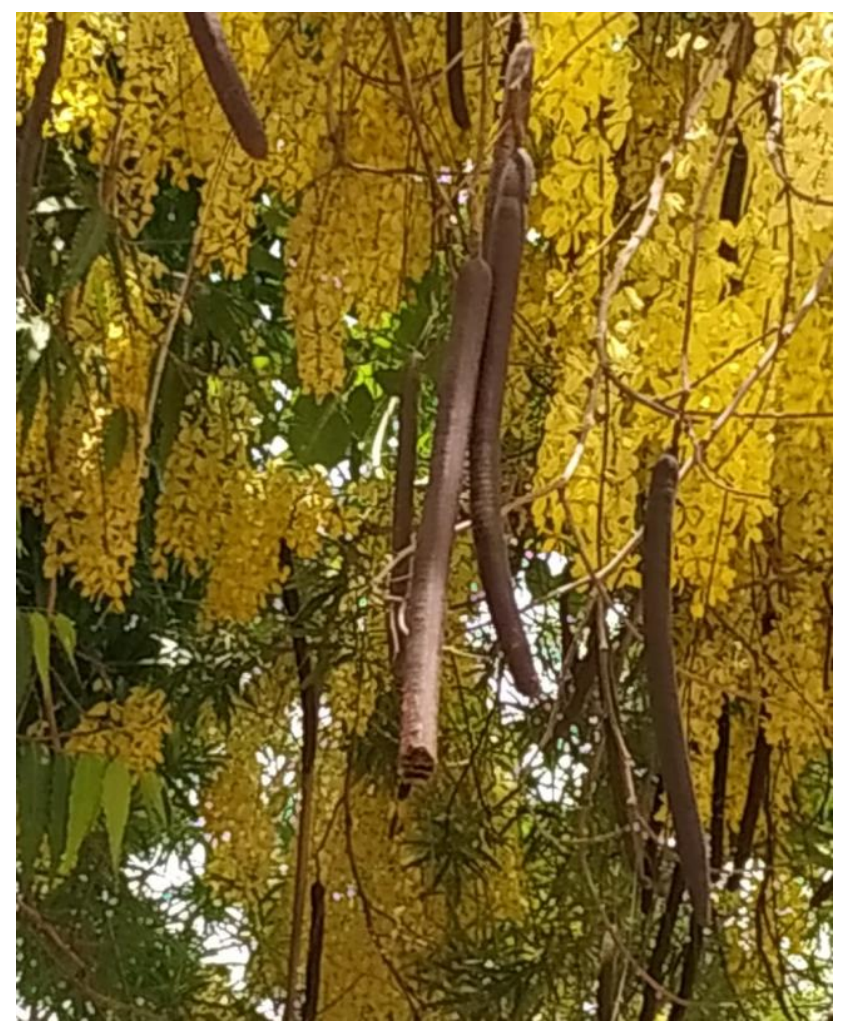

$b$

Figure 3. C. fistula:

$\boldsymbol{a}$-flowering; $\boldsymbol{b}$ - mature fruits are dark brown and new flowers

A similar shift of dates of various phonological events in $C$. fistula trees growing in different cities of India has also been obtained. In Jaipur (Rajasthan), usually, the flowering in this tree was recorded in the first week of March for the last 15-20 years (Ashwani Kumar, personal communication). However, in 2019 flowering was delayed and floral buds emerged only in the third week of April. At Pathakot (Punjab) during 2018-2020, flowering commenced in the first week of April which continued till the end of June (Mr Vinayak, personal communication). Jain (Unpublished data) has recorded the effect of climate change on the phenology of $C$. fistula trees growing at Gwalior during 1974-2017. It was observed that during 1974-1976, leaf fall was recorded in January, February and March. New leaves emerged in April; the flowering periods were May, June and July, and fruiting was observed in July and August. Flowering between 1988-1990 was recorded in JuneAugust and 2014-2017; maximum leaf fall was seen in March, and a new flush of 
leaves was observed in May, flowering in May-August and fruiting in September. These observations revealed that the phonological events, flowering, in particular, shifted from May-July to May-August. It was associated with the temperature rise. In May 1974 it was $42.6^{\circ} \mathrm{C}$, and in May 1976 it was $43.1^{\circ} \mathrm{C}$. Similarly, the maximum temperature in May in 1988 was $42.5^{\circ}$, and in May 1990 it increased to $43.9^{\circ} \mathrm{C}$ and flowering was observed in May-August.

World over such an extension of phonological events in several trees has been recorded due to global warming. Chmielewski and Rötzer (2001) investigated the impact of climatic changes on plant development in Europe. In this study, the phenological data of the International Phenological Gardens for the period 19691998 was used and the leafing dates of four tree species (Betula pubescens, Prunus avium, Sorbus aucuparia and Ribes alpinum) were combined in an annual leaf unfolding index to define the beginning of the growing season. This investigation showed that warming in the early spring (February-April) by $1{ }^{\circ} \mathrm{C}$ causes an advance at the beginning of the growing season of 7 days. It was concluded that the observed extension of the growing season was mainly the result of an earlier onset of spring. An increase of mean annual air temperature by $1^{\circ} \mathrm{C}$ led to an extension of 5 days. These results confirm the findings of other authors, concerning the influence of air temperature on the timing of spring events. In most recent studies, an advanced timing of spring events such as budding, leafing and flowering between 2 and 4 days per degree was found (Beaubien \& Freeland, 2000; Kramer et al., 2000; Sparks et al., 1997). Chmielewski et al. (2004) observed that the distinct changes in air temperature since the end of the 1980s have led to clear responses in plant phenology in many parts of the world. In Germany phenological phases of the natural vegetation as well as of fruit trees and field, crops have advanced clearly in the last decade of the $20^{\text {th }}$ century.

Milošević et al. (2013) investigated the dates of occurrence of phenological phases of selected plants (oxeye daisy, beech, apple, winter wheat and maize) with temperature threshold of $5^{\circ} \mathrm{C}$ and $10^{\circ} \mathrm{C}$ in the Republic of Slovenia. They observed that there was a tendency of the earlier appearance of spring phenological phases and later appearance of autumn phenological phases, and as a result, there was an extension of vegetation periods. Oteros et al. (2015) analyzed the effect of climate change on phenology in five crops (oats, wheat, rye, barley and maize) at 26 sites growing in Spain in 1986-2012. The most noticeable advance in spring phenology was recorded for wheat and oats. In these two crops, the "Flag leaf sheath swollen" and "Flowering date" phenophases were brought forward by around three days/year and one day/year, respectively. Temperature changes during the period before phenophase onset were identified as the cause of these phenological trends. Over recent years, weather conditions worldwide have been changing at a remarkable 
speed. Global warming is a scientific fact: average global surface air temperatures have increased by over $0.6^{\circ} \mathrm{C}$ between 1951 and 2010, and the increase is very likely to persist over the short term, i.e., into the next century.

Conclusions. In the light of the observations recorded on phenophase and those of others presented in support, it is concluded that the shift in the timing of various phenoevents is the trees of $C$. fistula at Agra (India). They are influenced by the change in the climate and rise in temperature. It is suggested that a phenological model should be developed in order to estimate the impact of climate change on plant development in different regions of India. Efforts are necessary to estimate the impacts of temperature rise on fruit trees, horticultural plants and crops.

Acknowledgement. Sincere thanks are due to our revered teacher Late Professor N. C. Mukerjee, for suggesting the problem. Thanks are due to Professor Ashwani Kumar, Rajasthan University (Jaipur); Professor Ashok Jain, Jiwaji University (Gwalior); Mr Suresh Tandon (Agra) and Mr Vinayak (Pathankot) for valuable information and suggestions. Thanks are due to Ms Katyayni and Ms Shubhangi for graphic presentation of data on temperature.

\section{References}

Ahas, R., Jaagus, J., \& Aasa, A. (2000). The phenological calendar of Estonia and its correlation with mean air temperature. International Journal of Biometeorology, 44(4), 159-166.

Anonymous (2013). Statistics Related to Climate Change-India. Ministry of Statistics and Programme Implementation. Central Statistics Office, Social Statistics Division, Govt. of India, New Delhi, 1-280.

Anonymous (2019). Annual report. India Meteorological Department. Ministry of Earth Sciences, Govt. of India, New Delhi, 1-166.

Beaubien, E. G., \& Freeland, H. J. (2000). Spring phenology trends in Alberta, Canada: links to ocean temperature. International Journal of Biometeorology, 44(2), 53-59.

Both, C., Artemyev, A. V., Blaauw, B., Cowie, R. J., Dekhuijzen, A. J., Eeva, T., ... \& Visser, M. E. (2004). Large-scale geographical variation confirms that climate change causes birds to lay earlier. Proceedings of the Royal Society of London. Series B: Biological Sciences, 271(1549), 1657-1662.

Chmielewski, F. M., \& Rötzer, T. (2001). Response of tree phenology to climate change across Europe. Agricultural and Forest Meteorology, 108(2), 101-112.

Chmielewski, F. M., Müller, A., \& Bruns, E. (2004). Climate changes and trends in phenology of fruit trees and field crops in Germany, 1961-2000. Agricultural and Forest Meteorology, 121(1-2), 69-78.

Duraipandiyan, V., Baskar, A. A., Ignacimuthu, S., Muthukumar, C., \& Al-Harbi, N. A. (2012). Anticancer activity of Rhein isolated from Cassia fistula L. flower. Asian Pacific journal of tropical disease, 2, S517-S523.

Kramer, K., Leinonen, I., \& Loustau, D. (2000). The importance of phenology for the evaluation of impact of climate change on growth of boreal, temperate and Mediterranean forests ecosystems: an overview. International Journal of Biometeorology, 44(2), 67-75. 
Kumar, K. A., Satish, S., Sayeed, I., \& Hedge, K. (2017). Therapeutic Uses of Cassia fistula: Review. International Journal of Pharma and Chemical Research, 3(1), 38-43.

Milošević, D., Žiberna, I., \& Savić, S. (2013). Analysis of the climate change in Slovenia: Changes in plant development under the influence of meteorological parameters in the period 19612011 (Part II). Bulletin of the Serbian geographical society, 93(2). DOI: 10.2298/GSGD1302001M.

Misra, P. (2020). Carbon Neutral Agra: How do we make it happen? Why on Earth. Environment. YKA Media Pvt Ltd.10th June, 2020.

Murali, K. S. (1993). Differential reproductive success in Cassia fistula in different habitants - A case of pollinator limitations? Current Science (Bangalore), 65(3), 270-272.

Oteros, J., García-Mozo, H., Botey, R., Mestre, A., \& Galán, C. (2015). Variations in cereal crop phenology in Spain over the last twenty-six years (1986-2012). Climatic Change, 130(4), 545-558. DOI 10.1007/s10584-015-1363-9.

Parmesan, C., \& Yohe, G. (2003). A globally coherent fingerprint of climate change impacts across natural systems. Nature, 421(6918), 37-42.

Pole, S. (2012). Aragvadha. Ayurvedic Medicine: The Principles of Traditional Practice. Singing Dragon. Part 2. 129.

Root, T. L., Price, J. T., Hall, K. R., Schneider, S. H., Rosenzweig, C., \& Pounds, J. A. (2003). Fingerprints of global warming on wild animals and plants. Nature, 421(6918), 57-60.

Schwartz, M. D. (1999). Advancing to full bloom: planning phenological research for the $21 \mathrm{st}$ century. International Journal of Biometeorology, 42(3), 113-118.

Sparkes, T. H., Carey, P. D., \& Coombes, J. (1997). First leafing dates of trees in Surrey between 1947 and 1996. London Naturalist, 76, 15-20.

Vaidya, B. D. (2002). Materia Medica of Ayurveda. India: B. Jain. Retrieved, November 10, 2012. P. 41-42. URL: https://books.google.com.ua/books?id=i-IU3D6Cl3sC\&pg=PA41\&dq=purga tive+ aragvadha\&redir_esc $=\mathrm{y} \& \mathrm{hl}=\mathrm{uk} \# \mathrm{v}=$ onepage $\& \mathrm{q} \& \mathrm{f}=$ true. 